\section{BRIDGING THE GAP}

Neurohistochemistry

Edited by C. W. M. Adams. Pp. vii + 753. (Amsterdam, London and New York: Elsevier Publishing Company, 1965.) $160 s$.

THE title of this book is slightly misleading as the contents cover a much wider field. Although the greater part has been written by the editor, there are ten other contributors. The work is divided into three sections, in which histochemistry is dealt with as a technique, in relation to the investigation of normal nervous tissue, and in connexion with neuropathology.

The editor's introduction emphasizes the importance of histochemistry in bridging the gap between conventional histology and the biochemistry of homogenized tissues. $\mathrm{He}$ appears to regard it as more closely orientated towards histology and thus as an extension of a staining technique. This is far too limited, for as Glenner points out in his chapter: "the potential of histochemistry is great for it offers an unexcelled opportunity to relate cellular and intracellular structure to physiologic function". Furthermore, most pathologists would hope that modern histochemistry might be able to reveal collular abnormalities underlying "biochemical lesions" in tissues which are known to be functioning abnormally but in which no abnormality of structure can be detected by conventional histological methods.

The opening part of the book is devoted to histochemical methods and is not intended to be exhaustive. It thus gives a very useful introduction to the subject and an adequate bibliography is available for those who wish to delve deeper into the subject. In addition to histochemical methods, techniques for single-cell examination and autoradiography are included and future developments taken care of by a chapter on electron histochemistry by Torack, and all of this is very valuable. The distinction between histochemistry and cytochemistry is made very sharp chiefly because of the different methods of preparation. In the broader search for knowledge this distinction is artificial, for each technique makes its own contribution to the final composite picture of a pathological lesion. On the whole, this histochemical section is satisfactory, though there are a number of minor points which call for comment. For example, it is stated on page 11 that acetylation of Sudan black gives rise to "improved staining" though this is by no means certain; on page 85 Deitch $^{1}$ is credited with the introduction of 2-4-dichlorophenol in the Sakaguchi reaction, though this was recommended by McLeish et al. in 1957 (ref. 2). On page 88, glycogen is said to be bound to protein (desmoglycogen), yet Meyer and Jeanloz ${ }^{3}$ proved that although it may be mechanically included in coagulated protein it is never chemically bound to it. On page 91, it is stated that there is uncertainty about the mechanism of metachromasia, although the physical chemistry of this subject has bcen worked out by Michaelis several years ago. Glenner deals very fully with enzyme histochemistry, and his discussions on factors affecting enzyme localization and characterization are most timely. Quantitative methods are discussed by Glenner and also by Davidson and Gregson in a later chapter on the cytochemistry of the nervous system. In the first section of the book there is a large amount of useful information on lipids and this embodies much work done by Prof. Adams and his colleagues.

The future of histochemistry is so closely bound up with pathology that the last section is particularly welcome. It is in many ways, perhaps not surprisingly, the most interesting part and the editor is able to convey his enthusiasm for the subject of myelin and the demyelinating diseases. So often in the past histochemistry has been dealt with as a subject on its own and often neglected by pathologists. The chief value of this work will be to encourage the neuropathologist to supplement conventional techniques with modern chemical methods, and the general background of histochemistry in the book will be sufficient to enable him to embark on a new discipline. For the painstaking production of this excellent work Prof. Adams is greatly to be congratulated, and he can feel assured that it will remain the standard work on this subject for many years to come. It may well result in the appearance of similar volumes on other specialized branches of pathology.

The production of the book is of high quality and attractive, and the illustrations of an equally high standard. Errors are few, though one mentions somewhat reluctantly that histochemistry is spelled "hystochemistry" on the page of contents. G. J. CUNNINGHAM

${ }^{1}$ Deitch, A. D., J. Histochem. Cytochem., 9, 477 (1961).

2 McLeish, J., Bell, L. G. E., La Cour, L. F., and Chayen, J., Exp. Cell Res., 12,120 (1957).

s Meyer, K. H., and Jeanloz, R. W., Helv. Chim. Acta, 26, 1784 (1943).

\section{Space Travel and Exploration}

By Harrie Massey. (A Contemporary Physics Reprint.) Pp. iv +117 . (London: Taylor and Francis, Ltd., 1966.) $18 s . ; \$ 2.60$.

Between February 1964 and June 1965 Sir Harrie Massey contributed a series of articles on space research and exploration to the journal Contemporary Physics. These articles have now been collected and published as a paperback volume, with notes on some more recont developments. The book begins with a swift survey of the main uses of artificial satellites and space vehicles. Then comes discussion of "Ways and Means", covering the velocity requirements for space missions, the types of rocket, methods of tracking, and the design of solar colls. The third section gives some results of scientific studies of the Earth and its upper atmosphere, and the fourth section is concerned chiefly with the Sun's influence over the Earth's atmosphere. Section 5 begins with lunar and planetary probes, and then returns to the mundane applications of satellites in meteorology and communications. The next section has biology as its theme and, appropriately enough, splits neatly into two halves: (a) "can there be micro-organisms living in space or on planets?" and $(b)$ "can we keep macro-organisms (especially homo sapiens) living happily in space?" Finally there are the notes on recent advances, up to late 1965 .

No one has a better appreciation of space research in all its aspects than Sir Harrie Massey, and his book provides a clear and well-balanced review of the major developments up to 1965 . Much of the detail had to be left out, of course, and readers who wish to pursue particular items in greater detail will find it difficult to trace the original papers, since no references are given. The book list at the end is not really adequato as a substitute and is indeed sometimes slightly capricious in its choices. Apart from this very slight imperfection, however, the book can be strongly recommended as a sound introduction to the present state of space research.

\section{G. KING-HELE}

\section{Friction and Wear in Machinery}

Edited by G. Herrmann. Translated from the Russian. Pp. $x+334$. (New York: Tho American Society of Mechanical Engineers: London: Pergamon Press, Ltd., 1960.) n.p.

THrs is a collection of papers on wear, friction and lubrication which describe work carried out at the Institute for the Science of Machines of the Academy of Sciences in Moscow. The papers were presented at a seminar there in 1955-56. The English translation, which is well done under the editorship of Dr. G. Herrmann, was made under the auspices of tho American Society of Mechanical Engineers. Some fifteen papers are presented. The 